\title{
MEASUREMENT OF STATURE FROM ARM-SPAN - AN ANTHROPOMETRIC STUDY ON CHAKMA TRIBAL TRIPURI FEMALES
}

\author{
Keisam Anupama Devi' ${ }^{1}$ M Islam², Chinglensana $\mathrm{L}^{3}$
}

\section{HOW TO CITE THIS ARTICLE:}

Keisam Anupama Devi, M Islam, Chinglensana L. "Measurement of Stature from Arm-Span - An

Anthropometric Study on Chakma Tribal Tripuri Females". Journal of Evolution of Medical and Dental Sciences 2014; Vol. 3, Issue 04, January 27; Page: 876-881, DOI: 10.14260/jemds/2014/1918

\begin{abstract}
CONTEXT: Arm span is the most reliable body parameter for predicting the stature of an individual. It is useful in predicting age related loss in stature and in identifying individuals with disproportionate growth abnormalities and skeletal dysplasia. Since in Tripura variegated ethnic groups inhabit in different climatic, nutritional and ecological conditions, no single anthropometric formula is suitable. The present study was undertaken to measure the stature, as well as arm-span and to determine whether there is any correlation between the stature and the arm-span. And to estimate using respective multiplication factors the stature from arm span and to assess the effectiveness of the above estimation by comparing the 'estimated' values with the measured' values. STUDY DESIGN: Cross sectional descriptive type of study. MATERIALS AND METHOD: The study was carried out with a total number of 100 Chakma adult female aged between 25 to 45 years. Armspan along with their stature was measured directly from the subjects by using anthropometric technique by a measuring tape. The data were then statistically analyzed by computation to find out its normative value. Multiplication factors were estimated for estimating stature and comparison were made between measured and estimated stature using paired " $\mathrm{t}$ " test. RESULT: The mean normal value of the arm-span was $148.74 \pm 5.34 \mathrm{~cm}$ and the stature was $149.26 \pm 5.82 \mathrm{~cm}$. The multiplication factor was estimated for the same hand measurements with the stature. Significant positive correlation was found in case of arm-span with the stature ( $\mathrm{r}=0.89$ ).
\end{abstract}

KEY WORDS: Anthropology, Correlation, Multiplication factor, Stature

INTRODUCTION: Measurement of the stature of patients is required for determination of basic energy requirements, standardization of measures of physical capacity and for adjusting drug dosage. However, in some situations the exact height can't be determined directly because of deformities of the limbs or in patients who have undergone amputation ${ }^{1,2}$. In such circumstances, an estimate of the height has to be computed based on other body parameters. These estimations are also of prime importance in predicting age related loss in stature, identifying individuals with disproportionate growth abnormalities and skeletal dysplasia or height loss during surgical procedures on the spine ${ }^{3}$. Several studies have reported the effectiveness of using various body parameters in predicting body stature and the arm span was found to be the most reliable ${ }^{3}$. However the association of arm span and height was found to vary from race to race ${ }^{4}$. Even though several studies of this nature are available on Bengali populations of west Bengal, no data is available on tribal or Bengali population of Tripura. Arm span is the horizontal distance between the tip of the middle fingers, with the arm extended laterally and at shoulder level ${ }^{5}$. Arm span is considered a useful alternative to stature, particularly in the elderly, since arm span does not vary significantly with age ${ }^{6,7}$. The Chakma Adivasi, a distinguished matriarchal community of Bangladesh living in the 


\section{ORIGINAL ARTICLE}

north parts of the Tripura especially in north Tripura, Unakuti and Dhalai districts close to the Bangladesh border.

METHODS: The study was basically observational, cross-sectional and descriptive in nature. The study was carried out on 100 Chakma adult females at different locations of Unakuti and Dhalai district. To measure the stature the subject was said to stand with her heel together and her back as straight as possible so that her heels, buttocks, shoulders and the head touched the wall. The arms were hung freely by the sides with the palm facing the thighs ${ }^{8}$. After asking the subject to take a deep breath and holding it, a measuring scale (steel plate) was placed against the head and wall to determine maximum height on the wall, and this was marked. The subject was then told to breathe and to step away from the wall. The height was then measured from the floor to the mark on the wall with steel tape which represents the stature in centimeters to the nearest 0.1 centimetres $^{8}$. Arm span was measured with a flexible steel tape from the tip of the middle finger on one hand to the tip of the middle finger on the other hand with the individual standing with her back to the wall with both arms abducted to 90 . The elbows and wrists extended and the palms facing directly forward. Readings were taken to the nearest 0.1 centimeters. Each subject was measured twice. When the two measurements for each parameter agreed within 0.4 centimeters, their average was taken as the best estimate for the true value. When the two initial measures did not satisfy the 0.4 centimeters criterion, two additional determinations were made and the mean of the closest records was used as the best estimate.

Calculation of multiplication factor: Each multiplication factor is the ratio of the stature to the respective physical measurements. A mean multiplication factor was then calculated for each measurement. These mean multiplication factor were used for estimating the stature from those variables.

Stature

M.F =-

Upper limb variables (e.g. Arm span)

Statistical analyses of data: Results were prepared on the basis of collected data and their distribution, central tendencies and standard deviations (SD) were calculated using a computer based program (SPSS version-11.5 \& MS Excel). Regression analyses were done. Mathematical relationships between sets of two measurements were calculated as multiplication factor (i.e., ratios between the two).Using the paired- $t$ test, the measured values were compared with the corresponding values estimated (using the corresponding multiplication factor) from other relevant measurement.

RESULTS: As mentioned in Methods, measurements of stature and arm span were taken using direct physical procedure in 100 subjects. Mean and standard deviation were calculated for each variable and frequency distribution was also determined. Multiplication factor was calculated for estimating stature from each arm span measurement. Correlation of arm span with stature was also assessed. The effectiveness of the use of the multiplication factor in these estimations was tested by testing whether there are significant differences. The stature of the 100 Chakma adult female subjects 
ranged from 133.00 to 162.50 centimeters, as shown in Table 1. The mean ( \pm SD) of the stature was found $148.74 \pm 5.34 \mathrm{~cm}$ and arm span was $149.26 .74 \pm 5.82$ (Table-I). In more than $80 \%$ of the subjects, the arm span was between 148.00 and $162.00 \mathrm{~cm}$ (Fig. 2). The arm span showed significant positive correlation $(\mathrm{r}=0.89, \mathrm{p}=0.000)$ with the stature (Figure 3). The multiplication factor (M.F.) regarding the arm span for estimating stature is mentioned in Table I. In this study, arm span was multiplied by mean multiplication factor and then estimated stature was obtained and then calculating the mean for 100 estimated values. This is shown in Table-II.

\begin{tabular}{|c|c|c|c|c|}
\hline Variable & Range $(\mathrm{cm})$ & $\begin{array}{c}\text { Mean } \\
(\mathrm{cm}) \pm \text { SD }\end{array}$ & $\begin{array}{c}\text { Mean } \\
\text { Multiplication } \\
\text { factor }\end{array}$ & $\begin{array}{c}\text { Significance of } \\
\text { correlation } \\
\text { P value }\end{array}$ \\
\hline Stature & $133.00-162.50$ & $148.74 \pm 5.34$ & - & - \\
\hline Arm span & $134.50-163.00$ & $149.26 \pm 5.82$ & 0.996 & 0.00 \\
\hline \multicolumn{3}{|c|}{$\begin{array}{r}\text { Table I: Stature and arm span, their descriptive statistics, } \\
\text { multiplication factors and correlation with stature }\end{array}$} \\
\hline
\end{tabular}

n: 100 for each variable S: significant at 5\% level in regression analysis

\begin{tabular}{|c|c|c|c|c|}
\hline \multirow{2}{*}{$\begin{array}{l}\text { Measurement from which the } \\
\text { stature was estimated }\end{array}$} & \multirow{2}{*}{$\begin{array}{l}\text { Measured status } \\
(\mathrm{cm}) \text { Mean } \pm \text { SD }\end{array}$} & \multicolumn{2}{|c|}{ Estimated stature $(\mathrm{cm})$} & \multirow{2}{*}{$\begin{array}{c}\text { Significance of } \\
\text { difference } \\
\text { P value }\end{array}$} \\
\hline & & Range & Mean \pm SD & \\
\hline Arm span & $148.74 \pm 5.34$ & $\begin{array}{l}133.50- \\
162.00\end{array}$ & $148 \pm 5.42$ & 0.96 \\
\hline
\end{tabular}

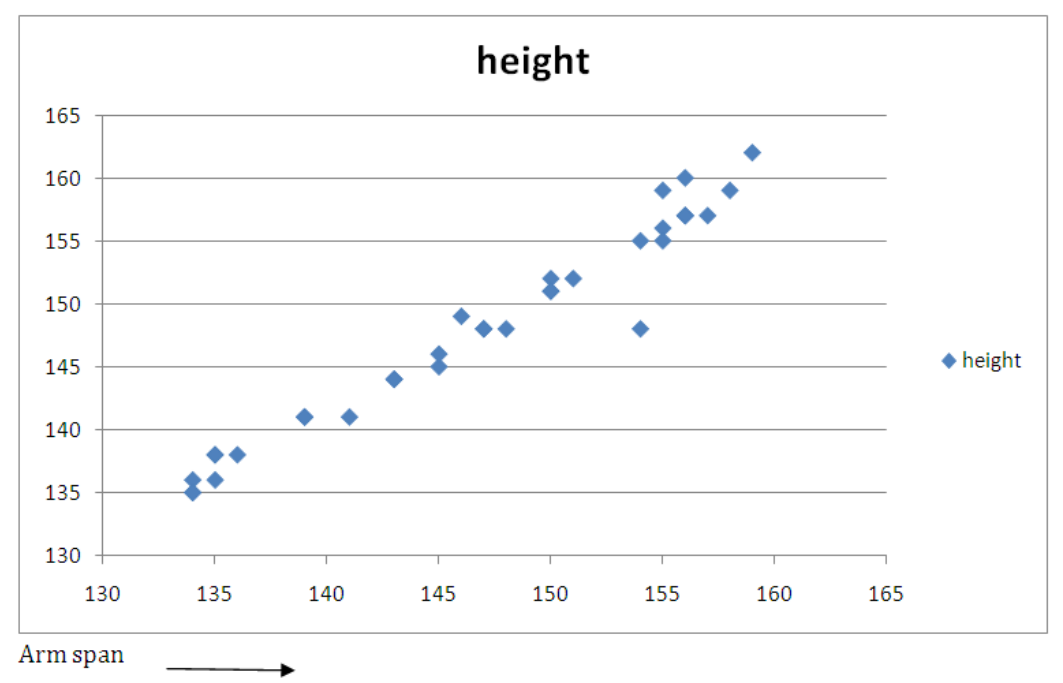

Table III: Scatter diagram with regression analysis showing significant $(\mathrm{p}<0.001)$ positive correlation $(r=0.89)$ between the stature and the arm span of the Chakma adult female $(n=100)$ 
DISCUSSION: Although there was no similar study in the said population to analyze the results of the present study and to compare with other studies, some observations may be worth mentioning. The mean arm span of the subjects of the present study was 149.26 5 .82. Higher value was seen in the Caucasian such as Spaniard females and Afro- Caribbean (Negroid) studying in the Oxford university ${ }^{9}$. Oriental groups were almost similar in their mean arm span value to a greater extent ${ }^{10}$. Afro-Caribbean had the highest mean arm span among the arm span considered 9 . As the Chakma tribe belongs to the Mongoloid race, some similarities are expected to exist with the other ethnic groups of Mongoloid race but we have found that variation is present among mongoloid race also. A study on Malaysian females showed mean arm-span nearer to this value of the Chakma females ${ }^{11}$. If we see the other ethnic groups such as Urban Bengali females, South and North Indians females ${ }^{12,13}$ of India and Asians studying in Oxford Brooks University ${ }^{10}$, we have found that all of them considered in this study showed higher value than this. In the present study, the mean stature of the Chakma females was found as148.74 \pm 5.34 centimeters. The mean stature of the Japanese and Chinese females has been found somewhat closer to this value. The urban Bengali females ${ }^{12}$ and the females of some Indian ethnic groups like South Indians ${ }^{1}$ appear to show a higher mean stature than the Chakma females. However, rural Bengali females ${ }^{14}$ and Indians like Santhals of West Bengal ${ }^{15}$ had lower value than the Chakma female population. A little higher value was observed in Bangladeshi Garo females ${ }^{5}$. Higher mean stature was also being noted in the Caucasian females of Mexican ${ }^{6}$ origin. It should be noted that the highest mean stature was found in the Negroid adult females like the Somali in Ethiopia 4 . From the above view it may be suggested that variation is not only present in between races or ethnic groups but also present among individual races or ethnic groups.

CONCLUSION: Though the sample size was small and the convenience sampling had to be applied due to time constraints as well as because the study was done on such a group of people where a sampling frame could not be constructed, results of the present study will provide a baseline information, regarding some variables of a particular population (defined for the present study as Chakma females). It could be lead to the development of a standard for such data on various subgroups of the population (and the population as a whole). Comparisons made with other population could contribute to the understanding of the relative status of our Chakma population in the context of the anthropometric variations around the world. Significant correlations, as detected in the study between some of the measurements and their implications in the development of proper multiplication factors to be useful in estimating one measurement from another. This should encourage others in taking up further research in the field. A similar study might be done on other tribes like Tipra, Jamatia, Reang, Murong and others, and relationship of stature with other parameters (lower limb dimensions etc.) of the body could also be considered.

\section{REFERENCES:}

1. Mohanty SP, Babu SS, Nair NS. The use of arm span as a predictor of height: A study of South Indian women. Journal of Orthopaedic Surgery [Online], 9(1). Available from: www.josonline.org/PDF/v9i1.pdf [Accessed on 19th January 2009]. 2001.

2. Lal CS, Lala JK. Estimation of height from tibial and ulnar length in North Bihar. Journal of Indian Medical Association [Online], 58(4). Available from: http//www.ncbi.nlm.nih.gov/ 
PubMed/5021709 [Accessed on 28th November 2008]. 1970.

3. Zverev Y, Chisi J. Estimating height from arm span measurement in Malawian children. Cell 2005 Dec; 29(2):469-73

4. Lucia E, Leema F, Tesfaye F, Demisse F, Ismail S. The use of arm span measurement to assess the multinational status of adults in four Ethiopian ethnic groups. European Journal of Clinical Nutrition [Online], 56. Available from; http:// www.nature.com/ ejcn/journal/v56/n2/full/1601289a.html [Accessed on 11th June. 2002.

5. Samira Hossain, Jahan Ara Begum, Zakia Akhter. Measurement of Stature from Arm-span An Anthropometric Study on Garo Tribal Bangladeshi Females. Bangladesh J. Anat. 2011, 9(1): 5-9.

6. Lavender SA, Marras WS, Sabol RJ. A Study of Female Mexican Anthropometric Measures Useful for Workstation Design in Light Manufacturing Facilities. AIHA Journal [Online], 63. Available from: http://74.125.95.132/searchcR2aLkaNcc.edu/ publication\% [Accessed on 20thOctober 2008].2002

7. Frisancho AR. Anthropometric standards for the assessment of growth and nutritional status [Online]. USA. The University of Michigan Press. Available from: http:// www.books.google.com.bd/books? [Accessed on 20thJune 2008]. 1990

8. Humosim Anthropometric measurements [Online]. Available from: Center for Ergonomics. University of Michigan.1205 Beal Avenue. Ann Arbor, Michigan 48109-2117(734)763-570

9. Reeves SL, Varakamin C, Henry CJK. The relation between arm span measurement and height with special reference to gender and ethnicity. European Journal of Clinical Nutrition [Online], 50. Available from: http:// www.nature.com/ejcn/journal/v56/ [Accessed 29th June 2008]. 1996

10. Human Height [Online]. Available from: http://www. answers. com/ topic/ height [Accessed on 18th August 2007]

11. Shahar S, Pooy NS. Predictive equations for estimation of stature in Malaysian elderly people. Asia Pacific journal of Clinical Nutrition [Online], 12(1). Available from: URL http:// www.biomedexperts.com [Accessed on 17th August 2008]. 2003.

12. Laila SZH. Anthropometric measurements of the upper limb and their relationships with the stature and the hand shape, frame size and somato type of Bengali adult Muslim females. Thesis (MPhil). BSMMU, Bangladesh. 2008.

13. Agarwal AN, Gupta D, Ezekiel LMK, Jindal SK. Statistical estimation of height from arm span in north Indian subjects. Indian Journal of Physiology and Pharmacology [Online], 44(3). Available from: http:// www.ncbi.nlm.nih.gov [Accessed on 19thMay 2008]. 2000

14. Hosegood V, Campbell O MR. Body mass index, height, weight, arm circumference and mortality in Bangladeshi women: a 19y longitudinal study. American Journal of Clinical Nutrition [Online], 77. Available from: http://www.ncbi.nlm.nih.gov/ PubMed [Accessed on 5th December 2008]. 2003.

15. Ghosh S, Malik SL. Sex Differences in body size and shape among Santhals of West Bengal. Anthropologist [Online], 9(2). Available from: http://www.krepublishers.Journal-[Accessed on 23rdNovember 2008]. 2007. 


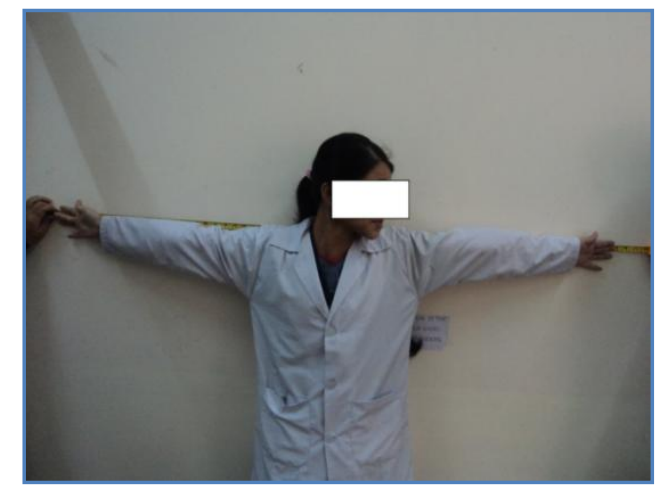

\section{Measurement of arm-span length}

\section{AUTHORS:}

1. Keisam Anupama Devi

2. M. Islam

3. Chinglensana L.

\section{PARTICULARS OF CONTRIBUTORS:}

1. Medical Officer, Manipur Health Service, Government of Manipur.

2. Assistant Professor, Department of Anatomy, AGMC \& GBP Hospital.

3. Registrar, Department of Surgery, Regional Institute of Medical Sciences and Hospital, Imphal.

\section{NAME ADDRESS EMAIL ID OF THE CORRESPONDING AUTHOR:}

Dr. Keisham Anupama Devi, W/o, Dr. Laitonjam Chinglensana, Singjamei Thongam Leikai, Opposite SROY Club Leirak, Imphal West, PIN - 795008.

E-mail: anupama.keisam@gmail.com

Date of Submission: 16/12/2013.

Date of Peer Review: 17/12/2013.

Date of Acceptance: 16/01/2014.

Date of Publishing: 22/01/2014. 